\begin{tabular}{cc} 
Revista de & Journal of Integrated \\
GESTÃO COSTEIRA Integrada COSTAL ZONEMANAGEMENT \\
\hline
\end{tabular}

\title{
Temporal evolution of the contamination in the southern area of the Patos Lagoon estuary, RS, Brazil
}

\author{
Mônica Wallner-Kersanach ${ }^{\mathrm{a},}$ a; Nicolai Mirlean ${ }^{\mathrm{a}}$; \\ Maria da Graça Zepka Baumgarten ${ }^{\mathrm{a}}$; Luiza Dy Fonseca Costa ${ }^{\mathrm{a}}$; Paulo Baisch ${ }^{\mathrm{a}}$
}

\begin{abstract}
The southern area of the Patos Lagoon estuary has been subjected to intense industrial and port-related activities which have not only caused meaningful changes in the landscape but also degraded aquatic resources by contaminating them with dissolved nutrients and trace metals in the last decades. This study aims at compiling data on the development that has happened in the urban and industrial occupation in Rio Grande, a city located in the south of Rio Grande do Sul, RS, Brazil, by relating it to the main results of contamination indicators in the estuarine environment regarding water, sediment, soil and atmosphere. Bibliographic data have shown an increase in domestic effluents around the city in the 1980's, mainly in more sheltered areas, such as the Saco da Mangueira, where cyanobacteria eutrophication has often occurred because of the high concentration of nutrients. The content of trace metals in the water of channel areas of the estuary was always lower than the maximum limit established by Brazilian quality criteria. However, the sediment showed higher concentrations of some trace metals (e.g. copper, lead, nickel, vanadium and zinc), the metalloid $\mathrm{As}$ and $\mathrm{Hg}$ than the maximum concentrations established by the legislation, mainly in several places around urban, industrial and port areas. The labile fraction (or potentially bioavailable) in the water and in the sediment showed that trace metals have provided significant contributions to sheltered areas, such as marinas, but have exceeded in shipyards. Trace metals in the urban soil and man-made ground of the city indicated that there were anthropogenic contributions, mainly by mercury. Anomalies in the content of lead found in the atmospheric particulate matter and acid rain were also reported. Therefore, more severe environmental policies, effective control, industrial wastewater treatment and control of atmospheric emissions must be carried out in order to maintain environmental quality and public health. The city authorities in Rio Grande need to implement the existing integrated estuary management program in a proper and practical way, involving stakeholders and local governments.
\end{abstract}

Keywords: contamination, nutrients, trace metals, estuary, environmental management

\footnotetext{
(a) Corresponding author to whom correspondence should be addressed.

${ }^{\text {a }}$ Universidade Federal do Rio Grande (FURG), Rio Grande, RS, Brazil. E-mails: Mônica Wallner-Kersanach <monicawallner@furg.br>; Nicolai Mirlean<dgeonmir@furg.br>; Maria da Graça Zepka Baumgarten <dqmmgzb@furg.br>; Luiza Dy Fonseca Costa <luiza_dy@hotmail.com>; Paulo Baisch<baisch@mikrus.com.br>.
}

*Submission:18 MAR 2015; Peer review: 27 APR 2015; Revised: 4 OCT 2015; Accepted: 8 OCT 2015; Available on-line: 10 OCT 2015

This article contains supporting information online at http://www.aprh.pt/rgci/pdf/rgci-596_Wallner-Kersanach_SupportingInformation.pdf
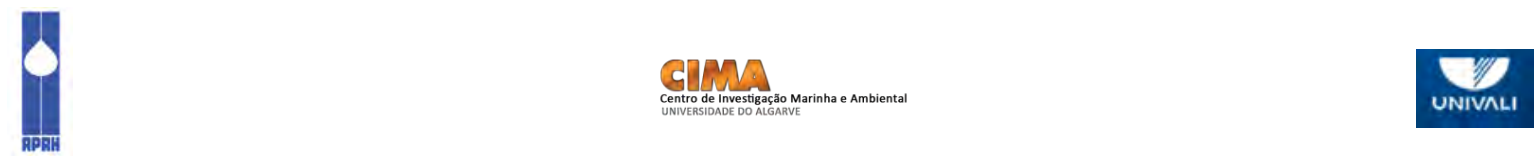


\section{RESUMO}

Evolução temporal da contaminação na área sul do estuário da Lagoa dos Patos, RS, Brasil

A parte sul do estuário da Lagoa dos Patos apresenta intensa atividade portuária e industrial, sendo que estas propiciaram nas últimas décadas alterações significativas na paisagem e na degradação dos recursos hídricos, incluindo a contaminação por nutrientes dissolvidos e por metais traço. Este estudo visa compilar uma revisão dos impactos resultantes do desenvolvimento da ocupação urbana, industrial e naval da cidade do Rio Grande ao longo dos anos, procurando relacioná-los com os principais resultados de indicadores da contaminação do ambiente estuarino nos compartimentos água, sedimento, solo e atmosfera da região. Os dados bibliográficos indicaram um acréscimo do lançamento de efluentes domésticos ao redor da cidade nos anos de 1980, principalmente em área mais abrigadas do estuário como o Saco da Mangueira, o que vem promovendo desequilíbrios tróficos (hipertrofia das águas de margem) e frequente florações de cianobactérias, devido ao aporte de nutrientes. Os teores de metais traço na água de áreas de canal no estuário se encontram dentro dos limites estabelecidos pela legislação vigente. Entretanto, o sedimento demonstrou altas concentrações de alguns metais traço (por ex. cobre, chumbo, níquel, vanádio e zinco), o metaloide As e o $\mathrm{Hg}$, acima do estabelecido pela legislação, principalmente em vários locais ao redor da área urbana, industrial e portuária da cidade. A fração lábil (ou potencialmente biodisponível) de metais traço em água e sedimento indicaram contribuições significativas em áreas abrigadas como marinas e excederam em áreas de estaleiros. Metais traço nos solos e os aterros da cidade mostraram contribuições antropogênicas, com destaque para o mercúrio. Anomalias nos teores de chumbo no material particulado atmosférico e chuva ácida foram também reportados. Urge uma política ambiental mais severa e com efetiva fiscalização, proibindo fluentes clandestinos, exigindo tratamento básico dos efluentes pelas indústrias e controle das emissões atmosféricas, que vise a manutenção da qualidade ambiental e saúde pública da população que vive na área estuarina. O poder público do município de Rio Grande deve implementar de forma apropriada e prática o existente programa de gestão integrada para o estuário, envolvendo as partes interessadas e governantes locais.

Palavras-Chave: contaminação, metais traço, nutrientes, estuário, gestão ambiental

\section{Introduction}

Estuaries hold a large number of organisms and high biological productivity. They are privileged areas not only because they favor their multiple use, regarding urban, port and industrial occupation on its shoreline, but also because their waters can be used for sailing, fishing and leisure activities (Clark, 2001). The multiple uses of the estuaries enable the input of anthropogenic elements in the aquatic environment not only through urban and industrial effluents, but also through the precipitation of industrial air emissions. Other events, such as accidental chemical release from vessels, may also affect the fauna and the flora of the estuarine environment in the short or in the long term, depending on how long the aquatic environment can stand it (Burgin \& Hardiman, 2011; Law et al., 2003). Therefore, activities that pose risk to the quality of the estuarine water may generate conflicts concerning the use of the environment. They may also harm other sectors such as local fisheries, which often have their production decreased (Cicin-Sain \& Knecht, 1998).

Assessment of the estuarine environmental quality is needed since it enables the temporal evolution of the impact of human related activities on local contamination to be followed, moreover providing diagnoses to be used as a basis of environmental management programs. In addition, it is a tool to be applied to environmental actions that are carried out by policy makers and environmental managers in order to improve the quality of the estuary. In general, studies of the estuarine environment and its surrounding area are conducted in a specific environmental compartment (water, sediment, biota, rainwater or dry atmospheric precipitations) for various years to verify the contamination level and its relation with the urban and industrial development of a region. This is the scenario of studies that have been carried out in the southern area of the Patos Lagoon estuary in the southern coast of Rio Grande do Sul, Brazil (e.g. Baumgartem et al., 1995; Mirlean et al., 2000, 2005b. 2008, 2009; Costa \& Wallner-Kersanach, 2013; Guttierrez, 2013).

This estuary has been receiving higher amounts of nutrients and trace metals of anthropogenic origin in the last 15 years due to the increase in port, naval and industrial activities in the region. Therefore, this study aims at providing knowledge about the impact of human related activities, namely the development of the urban and industrial in Rio Grande, the main city located in the southern shoreline of the Patos Lagoon. For this assessment, studies of nutrients in water and trace metals in water, sediment, soil and atmosphere that have been carried out in the study area for 35 years were considered.

\section{The Patos Lagoon and its estuarine area}

The Patos Lagoon stretches over $10,360 \mathrm{~km}^{2}$ on the coastal plain in the Rio Grande do Sul state. It is considered the largest choked-type coastal lagoon (Kjerfve, 1986) (Figure 1). Fluvial systems that comprise the hydrographic basin of the Guaíba system (the Jacuí, Taquarí, Caí, Sinos and Gravataí Rivers) are located in the north of the lagoon and supply $86 \%$ of its average total freshwater input. The freshwater discharge of the Guaíba River may vary from $41-22,000 \mathrm{~m}^{3} \mathrm{~s}^{-1}$ with an 

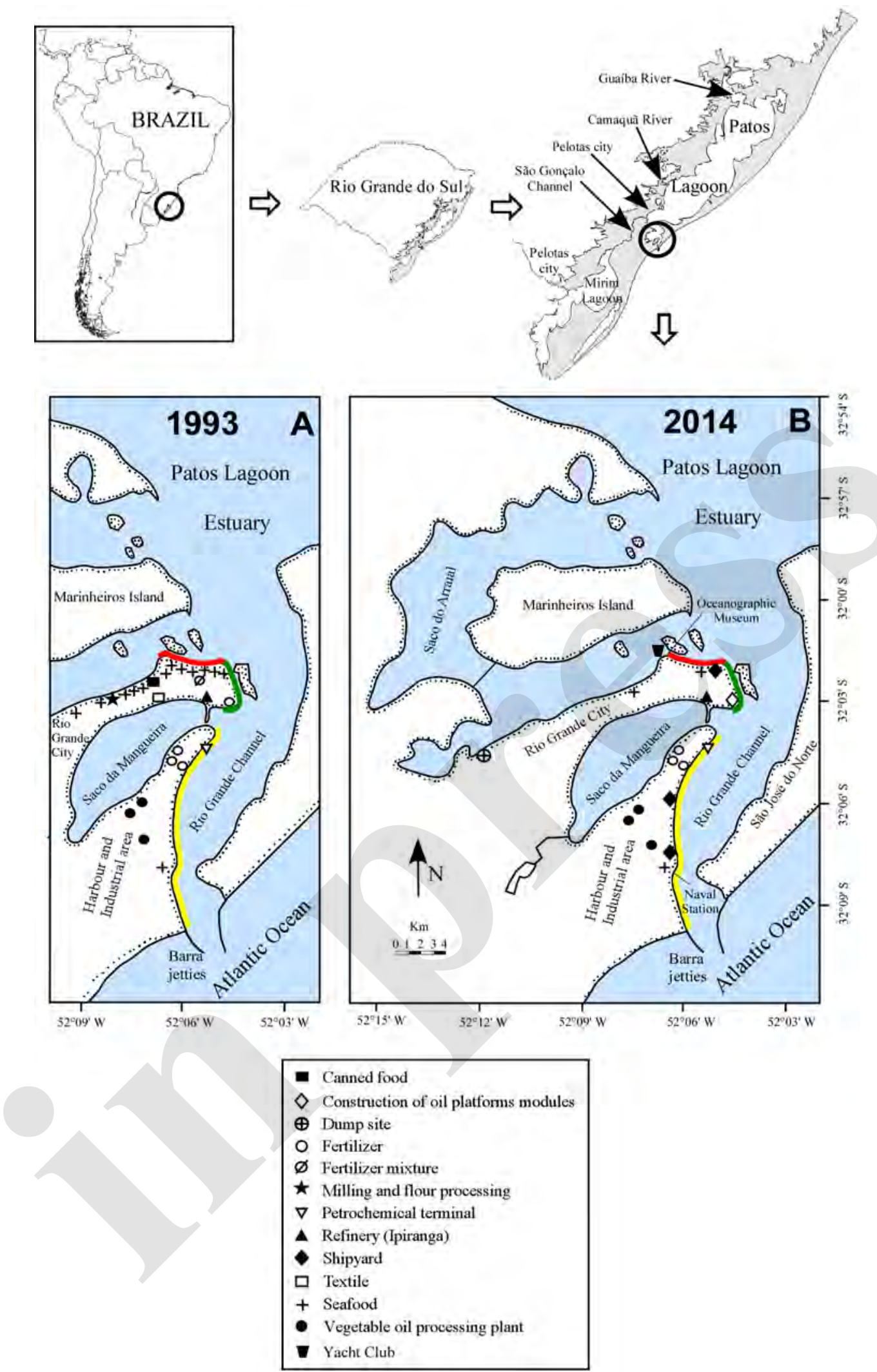

Figure 1 - The estuary of Patos Lagoon, the city of Rio Grande and the location of industrial, naval and port activities that contribute to potential contamination by wastewater and / or air emissions for the estuarine water during the years 1993 (A) and 2014 (B). Porto Velho ( $\square$ ), Porto Novo ( $\square$ ) e Super Porto ( $\square$ ). Figure A was adapted from Almeida et al. (1993).

Figura 1 - O estuário da Lagoa dos Patos, a cidade de Rio Grande e a localização das atividades indústriais, navais e portuárias que contribuem com uma potencial contaminação através de efluentes elou emissões atmosféricas para as águas estuarinas durante os anos de 1993 (A) e 2014 (B). Áreas portuárias: Porto Velho ( $\square$ ), Porto Novo ( $\square$ ) e Super Porto ( $\square$ ).

Figura A foi modificada de Almeida et al. (1993). 
annual mean around $1,000 \mathrm{~m}^{3} \mathrm{~s}^{-1}$. In the middle course, west of the lagoon, the Camaquã River is an important fluvial system because of its inflow contribution to the lagoon reaching $5,000 \mathrm{~m}^{3} \mathrm{~s}^{-1}$ during flood periods (Möller \& Castaing, 1999). The São Gonçalo Channel, whose aquatic contribution comes from the Mirim Lagoon, is located in the low course of the lagoon.

These rivers represent the major transport pathway of nutrients and suspended matter to the estuary. Because the Patos Lagoon is over $250 \mathrm{~km}$ long, the time that water takes to travel from Guaíba River (Figure 1) to the estuarine region is about 20 days (Herz, 1977). Therefore, nutrients originated from rivers have a high residence time within the lagoon before reaching the estuarine region, where biogeochemical processes may result in their consumption (Nienscheski et al., 1999).

The estuarine area of the Patos Lagoon stretches over the southern portion of the lagoon, where seawater entrance reaches its average limit in Ponta da Feitoria, close to Pelotas city (Möller \& Castaing, 1999). Even though the estuary has high hydrodynamic rate, mainly conditioned by the wind strength and direction, the tidal effect $(0.4 \mathrm{~m})$ is minor. Its narrow channel communicates with the Atlantic Ocean and enables high outflow of lagoon waters, which may reach $25,000 \mathrm{~m}^{3} \mathrm{~s}^{-1}$ in low tide (Herz, 1977). During winter (June-August) and El Niño events the high freshwater discharge practically replaces salt water and occupies the entire lagoon system (Pasquini et al., 2012) and the calculated freshwater residence time is $c$. 5 months (Windom et al., 1999).

The lagoon has high primary productivity which supports nurseries of several species of mollusks, crustaceans and fish that use this environment in their whole or partial life cycle (Odebrecht et al., 2010). Many species, such as the shrimp Penaeus paulensis, have commercial interest within the estuarine area. Since there are in this area activities related to the port, fishery, navigation, leisure, moreover transportation and vessel repair in this area, their impact can be seen in the vicinity of the estuary.

The estuarine area has been a receptor of several urban, industrial and agricultural effluents, especially from the cities of Rio Grande, Pelotas and São José do Norte (Odebrecht et al., 2010).

Several studies carried out in this estuary have shown that there is considerable contamination by trace elements pollutants in different environmental compartments (soil, sediment, water, biota) in the Rio Grande area (Garcia et al., 2010; Mirlean et al., 2005a, 2008; 2009). The chemical elements that stand out as subjects of concern because of their harmful effects on the environment and public health are $\mathrm{Pb}, \mathrm{Hg}$ and $\mathrm{As}$.

To understand the cause of this contamination by trace metals in the Rio Grande area is necessary to under- stand the history of the urban and industrial development of the city. The development of the city is related with the creation and expansion of the port area, which is divided in Porto Velho, Porto Novo and Super Porto (Text A in SI-I, see Supporting Information).

This development triggered the need to update the study conducted by Almeida et al (1993) as shown in Figure 1A, because Rio Grande only collects and treats about $33 \%$ of its sewage currently. Its treatment system has recently been expanded but, most peripheral areas do not have any sewage treatment yet. Therefore, a new assessment started in 2014 in the Saco da Mangueira, an inlet whose waters are receptors of a significant anthropogenic contribution from the south of the city (Aguiar et al., 2014). This study identified 49 effluents whose origin was anthropogenic and 2 pluvial ones. Taking into account that only 22 effluents had been identified in this inlet in 1993, there has been an increase in the input of contaminants.

These effluents were qualitatively analyzed to identify their level of contamination represented by the phosphorus concentrations. Phosphorus is one of the main constituents of the organic matter and can be found in significant amounts in domestic wastewater, food and fertilizer industries. A predetermined volume of reagent $(10 \%$ of the sample volume), previously prepared according to Baumgarten et al. (2010), was added to every effluent sample. The blue shades of the sample were compared to one of the six blue shades of a table, in which each blue shade was related to one different contamination level (Pinheiro et al., 2010).

Since there is no recommended limit for phosphorus effluent under Brazilian law Resolution 357 (CONAMA, 2005), the distinction between contaminated or uncontaminated samples was based on the concentrations reported in this legislation to freshwater Classes 2 and 3, which allow maximum values of 0.05 and $0.15 \mathrm{mg} \mathrm{L}^{-1}$. Concentrations up to $2 \mathrm{mg} \mathrm{L}^{-1}$ corresponded to very weak and weak contamination (Figure 2 Levels B and C), whereas concentrations of 3, 6 and $12 \mathrm{mg} \mathrm{L}^{-1}$ represented respectively a medium, strong and very strong contamination, respectively (Figure 2, levels D, E and F) (Pinheiro et al., 2010).

This mapping qualitatively identified the most contaminated effluents in terms of anthropogenic organic matter, thus showing which effluents will need to be monitored later in quantitative terms of their compositions and compared to the current legislation.

\section{Main contamination sources throughout urban and industrial development}

Urban development and the fishing industry expansion in the 1980's led to the assessment of water quality which determined the organic contamination of the wa- 


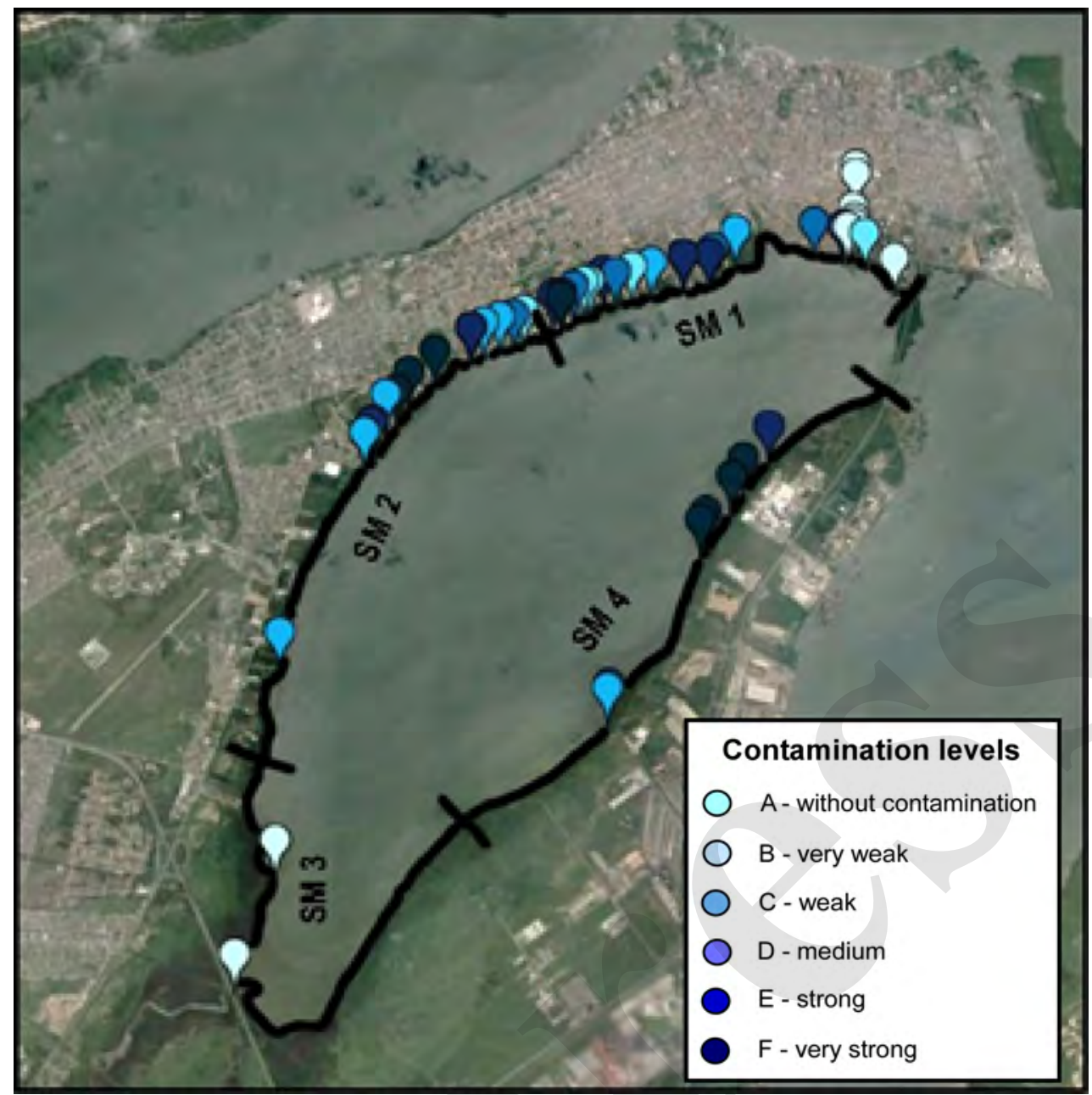

Figure 2 - The Saco da Mangueira, south of Rio Grande, indicating the sites of liquid effluent discharge and distinguished by the qualitative level of organic matter contamination according to Aguiar et al. (2014). The image is located between the latitude of $32^{\circ} 02^{\prime} \mathrm{S}$ and $32^{\circ} 08^{\prime} \mathrm{S}$ and the longitude of $52^{\circ} 04^{\prime} \mathrm{W}$ and $52^{\circ} 10^{\prime} \mathrm{W}$.

Figura 2 - O Saco da Mangueira, ao sul da cidade do Rio Grande indicando os locais de lançamento de efluentes líquidos e diferenciados pelo nível qualitativo de contaminação por matéria orgânica de acordo com Aguiar et al. (2014). A imagem encontra-se entre a latitude de $32^{\circ} 02$ 'S e $32^{\circ} 08^{\prime} \mathrm{S}$ e a longitude de $52^{\circ} 04^{\prime} \mathrm{W}$ e $52^{\circ} 10^{\prime} \mathrm{W}$.

ter around the city. After the change in the industrial profile of the city, most studies carried out in the second half of the 1990's focused on the port area, before the recent port expansion in the beginning of 2000. The studies had mainly on long-term objectives regarding the monitoring of the constituents of the water column and sediment in the Rio Grande Channel which flows into the estuary. These studies were carried out in the context of environmental assessments in Rio Grande. However, few of them have analyzed the anthropogenic contribution in terms of atmospheric contamination.

More recent studies (Bento et al., 2013; Costa \& Wallner-Kersanach, 2013; Aguiar et al., 2014;) have been carried out along the coastline of the city and the three port areas (Figure 1) to identify potential spots of contamination inputs. In order to better understand the evolution of the contamination studies in relation to the development that is going on in this region, they were organized in terms of environmental compartments, and focused on nutrients and trace metals, since these com- pounds are the most significant contributions to the environment.

\subsection{Water compartment}

\subsubsection{Nutrients}

Industrial development in the 1980's, mainly fishing industries and fertilizer plants, resulted in several changes in the estuarine water quality. The contamination observed at that time was related with oil and grease (Kantin et al., 1980), anionic detergents (Kantin et al., 1981) and dissolved ammonium, nitrate, nitrite and phosphate (Costa et al., 1982). The excess of those nutrients used to cause euthrophication in the waters along the coastline of the city, mainly in the Saco da Mangueira inlet and in the port area (Kantin et al., 1981; Almeida et al., 1984).

This environmental problem was mostly caused by the excessive content of nitrogenous compounds resulting from effluents rich in organic matter. These effluents 
have domestic origin or are discharged by fishing industries and vegetable grain processing units. In addition, phosphorus compounds originated from chemical fertilizer plants and domestic effluents were also reported.

Throphic unbalance in the estuary has been followed over the years (Baumgarten et al., 1995; Baumgarten, 2010; Odebrecht et al., 2010). Its result is the generation of euthrophication in the waters around Rio Grande (Baumgarten and Paixão, 2013), with cyanobacteria Microcystis aerruginosa blooms, which found favorable conditions to develop in the estuary (Yunes et al., 1995), moreover intense proliferation of cyanobacteria Aphanothec sp (Baumgarten, 2010). When the water quality of the Saco da Mangueira was compared with another estuarine inlet, farther from the city, Persich et al. (1996) observed that the former had larger phytoplankton biomass than the latter and, as a result, higher rates of euthrophication because it received more organic matter than it was able to depurate. This process was observed for ammonium and phosphate in the Saco da Mangueira, mainly associated to the Industrial District, where high values of Biochemical Oxygen Demand $\left(\mathrm{BOD}_{5}\right.$ were measured (Baumgarten, 2010).

High contribution of nutrients in the shallow waters was also observed at the northern area of the city where the municipal dumpsite is located. However, this high concentration was no further observed in the waters away from the shoreline (Sprengler et al., 2007) (Figure 1B).

Temporal assessments of concentrations of dissolved inorganic nitrogen (ammonium, nitrate, nitrite), dissolved inorganic phosphate and silicate in the Patos Lagoon estuarine waters, based on weekly data collected from 1983 to 1990 and on monthly data collected from 1993 to 2007, showed that there was high variation of the dissolved inorganic nutrients in water. Even though the concentration of phosphate and the sum of nitrite and nitrate had gradually increased from 1999 to 2001, they decreased significantly in 2002 and in 2003 when the El Nino effect led to higher freshwater discharge from the lagoon. In general, the lagoon hydrology is greatly affected by factors such as wind, rainfall and evaporation; thus, there is no distribution pattern of constituents which can be indicatives of organic contamination in the water column, mainly during extreme events (Abreu et al., 2010). It happens not only because the study areas are located in areas where there is high water circulation but also because such constituents do not persist in the water column. This process is suggested since nutrient removals occur with salinity zero to c. 5-7 and the organic matter mineralization could be a dominant process mainly in areas with salinity up to 25-27 in the Patos Lagoon (Window et al., 1999).

In the estuary channel, nutrients did not show any seasonal pattern because of the complex hydrographic of the Patos Lagoon by comparison with the inlets (Niencheski et al., 1999).

\subsubsection{Trace metals}

Trace metals, which are natural elements in the geological composition, contribute to aquatic environments, such as the Patos Lagoon, in dissolved and/or particulate forms. Their anthropogenic contributions to the southern estuarine area result mainly from the urban and industrial development of the Rio Grande city.

The impact caused by the municipal dump site of Rio Grande City in the salt marsh area and in the shore of the Saco do Martins (Figure 1B) was evident. The stream which receives the leachate indicated high $\mathrm{Pb}$ concentrations ranging from 0.93 to $1.60 \mathrm{mg} \mathrm{L}^{-1}$, by comparison with the maximum limits established by the legislation (CONAMA, 2005) of $0.5 \mathrm{mg} \mathrm{L}^{-1}$ for effluent launching (Sprengler et al., 2007).

However, the high outflow of the lagoon waters during low tide (Herz, 1977), along with extreme events or dredging activities in the port area have affected the concentrations of trace elements, both in water and in sediment. The monitoring of the total fractions of metals in water carried out in port areas located in the Porto Velho, the Porto Novo and the Super Porto from 1996 to 2001 showed significant decrease in the concentrations of copper, lead and zinc in the water. According to Barbosa et al. (2012), the average concentrations of $\mathrm{Pb}$, $\mathrm{Cu}$ and $\mathrm{Zn}$ were $3.86 \mu \mathrm{g} \mathrm{L}^{-1}, 26.85 \mu \mathrm{g} \mathrm{L}^{-1}$ and $23.43 \mu \mathrm{g}$ $\mathrm{L}^{-1}$, respectively, in 1997. There was a decrease in mean concentrations of $1.66 \mu \mathrm{g} \mathrm{L}^{-1}$ for $\mathrm{Pb}, 5.25 \mu \mathrm{g} \mathrm{L}^{-1}$ for $\mathrm{Cu}$ and $10.94 \mu \mathrm{g} \mathrm{L}^{-1}$ in 2000 . This process is attributed to the El Niño, which was one of the most powerful events during June/1997 and July/1998 and favored high discharge and the maintenance of freshwater in the estuary (Barbosa et al., 2012). In addition, the decrease in trace metals in both water and sediment observed in 2000 and in 2001 may have been also affected by the intense dredging activities carried out in the estuary.

Studies of water monitoring in port areas were conducted annually until 2012 (www.portoriogrande. com.br) and showed that the higher concentrations of metals $(\mathrm{Cr}, \mathrm{Cu}, \mathrm{Fe}, \mathrm{Pb}$ and $\mathrm{Zn})$ in the water column usually occurs in bottom waters with the sediment resuspension. Likewise, trace metal increases in the water have also been observed during the dredging activities while the sediment is resuspended in the estuary. However, 30 minutes after the end of the dredging process, some metal contents show almost the initial levels of concentration again (Table A in Supporting Information II) for $\mathrm{Cr}$ and $\mathrm{Pb}$ (Corradi et al., 2007). This may be likely explained by the low metal concentrations in water and the high hydrodynamic of the estuary causing dilution and dispersion of the elements. 
Studies of water quality have focused on the channel areas in the estuary over the years. Because of the low metal concentrations verified in the water column, currently, the main concern is the quality of the shallow waters along the coastline due to the industrial intensification process, including the naval one.

In the Patos Lagoon estuary, there are studies, which show the association of the metals, in dissolved and in the particulate fractions (Windom et al., 1999; Niencheski \& Baumgarten, 2000). The model of the behavior of dissolved trace elements in the Patos Lagoon estuary proposed by Window et al. (1999) suggests that, around salinity $5-7$, there is an increase in cobalt and nickel in the water due to cation exchanges and/or their desorption from particles due to the mix between freshwater and seawater. When salinity is around 25-27, there is an increase in most metals in the water because of the remineralization of organic matter and the remobilization of bottom sediment.

Even though the behavior of the total dissolved fraction of mercury and other trace metals/metalloids has been known for some time now, the potentially bioavailable fraction (the labile one) of metals in the water column was only known recently in this environment.

\subsubsection{Speciation of trace metals in water}

Recent studies in port areas of the Patos Lagoon estuary have applied analytical techniques to study speciation of trace metals, which analyze the labile or potentially bioavailable metal fraction in water or sediment. The estimation of this fraction, which may be incorporated more easily into the tissues of organisms, is more likely to represent a bioavailable fraction than the total metal (Leeuwen et al., 2005).

A technique that quantifies metal in its labile fraction was recently used with in situ passive samplers, the diffusive gradients in thin films (DGT), which integrates metal concentrations found in the environment through time, even in high hydrodynamic waters, such as estuaries. Moreover, this technique enables comparisons among geographically different areas (Davison \& Zhang, 1994).

The DGT technique started to be used in the Patos Lagoon estuary in 2003; the first time this technique was applied to estuaries in Brazil. It has still been used in the water to check the evolution of labile concentrations of some metals in the areas around the city. Taking into account the elements under analysis $(\mathrm{Cd}, \mathrm{Co}, \mathrm{Cu}, \mathrm{Mn}$, $\mathrm{Ni}, \mathrm{Pb}$ and $\mathrm{Zn}), \mathrm{Cd}, \mathrm{Cu}$ and $\mathrm{Pb}$ showed higher bioavailability in the water of two locations in the marinas north of the city, when compared with the less urbanized site, the Marinheiros Island (Wallner-Kersanach et al., 2009).

Due to the gradual release of trace metals from antifouling paints in vessels, marinas and ports were investi- gated in 2006 regarding the concentration of labile $\mathrm{Cu}$, which is found in high concentrations in these paints. Its variation was $0.11-0.45 \mu \mathrm{g} \mathrm{L}^{-1}$ in the marinas located in the Naval Station, the Porto Novo, the Oceanographic Museum and the Yacht Club whereas concentrations of $0.10-0.15 \mu \mathrm{g} \mathrm{L}^{-1}$ were found in the Porto Novo and the Super Porto (Petrobrás Terminal) (Figure 1). Concentrations of $\mathrm{Cu}$ were higher at the marinas since they are more sheltered and may be compared to areas with marinas in Australian estuaries which are densely populated with leisure boats (Dunn et al., 2004; Warnken et al., 2004).

After this contamination was detected, new studies were carried out in 2009 and 2010 to investigate the labile $\mathrm{Cu}$ and $\mathrm{Zn}$ in the estuary because of the high concentration found in antifouling paints used in that estuarine area. Two old shipyards, the marina of the Yacht Club and the Porto Novo were assessed. The Gustavo Fernandes Filho shipyard at the Porto Velho area and the Santos shipyard at the Super Porto showed the highest concentrations over the period of study. Labile $\mathrm{Cu}$ concentrations were approximately $0.45 \mu \mathrm{g}$ $\mathrm{L}^{-1}$ whereas labile $\mathrm{Zn}$ was close to $10 \mu \mathrm{g} \mathrm{L}^{-1}$ (Costa \& Wallner-Kersanach, 2013).

These studies showed that not only domestic and industrial effluents contribute to the contamination of estuarine waters. Navigation activities have been a potential source of trace metals from antifouling paints which are potentially avaliable to all organisms.

\subsection{Sediment compartment}

The assessment of trace metals in water reflects instantaneous contaminant concentration, but the sediment better depicts the long-term inputs. Therefore, studies with sediment in the Patos Lagoon estuary, especially on the channel areas, show contamination evidence, mainly by arsenic (As) and mercury $(\mathrm{Hg})$ (Mirlean et al. 2003a and b). The latter has been more investigated than the former in several studies, therefore, $\mathrm{Hg}$ will be presented in more detail in section 4.4.

The distribution and contamination of sediments by As in the Patos Lagoon estuarine area was first studied by Mirlean et al. (2003b). Studies of the sediment quality and of the monitoring of the dredging at the Rio Grande Port were conducted from 2002 to 2005 (www.portoriogrande.com.br). The highest concentration of As in the estuarine system (up to $50 \mathrm{mg} \mathrm{kg}^{-1}$ ) was found in the sediment at Porto Novo, Super Porto and adjacent channels (Figure 1B).

In the estuarine region, total levels of As had a strong increase: they were tenfold or twentyfold the values (2.5 and $7.7 \mathrm{mg} \mathrm{kg}^{-1}$ ) found in the sediment on the limnic region of the Patos Lagoon. In addition, the mobile (labile) form of As in the sediment found of the estuarine region at the Porto Novo also increases to $80 \%$ 
of the total value and $65 \%$ on average, whereas it increases to $63 \%$ of the total levels and $39 \%$ on average in the channels (Mirlean et al., 2003b). The mobile fraction is considered to be potentially bioavailable (Salomons and Förstner, 1984); thus, it shows the fraction that is capable of harming to the biota.

The study carried out by Mirlean et al. (2003b) shows that levels of As in most sediment at the Porto Novo (Figure 1) exceed the PEL (probable effect level) of 17 $\mathrm{mg} \mathrm{kg}^{-1}$ that represents the value above which the biota may be affected (Long et al., 1995). Some sediment samples exceed the SEL (severe effect level) of $33 \mathrm{mg}$ $\mathrm{kg}^{-1}$, which indicates that the biota will be severely affected. Some of these values were used to establish the legislation regarding the quality of the sediment that is used for dredging Brazilian jurisdictional areas (CONAMA, 2012). The Brazilian Sediment Quality Criteria for As are $19 \mathrm{mg} \mathrm{kg}^{-1}$ (Level 1 - threshold below the probability of a possible adverse effect to the biota) and $70 \mathrm{mg} \mathrm{kg}^{-1}$ (Level 2 - threshold above a possible deleterious effect to the biota).

Natural raw phosphorites and activities carried out by fertilizer plants are the main sources of sediment contamination by As in estuarine areas (Shumilin et al., 2001; Mirlean et al., 2003b). Elevated As concentrations higher than $300 \mathrm{mg} \mathrm{kg}^{-1}$ were found in the raw material and products used in this industrial sector. Analyses show that the content of As in phosphorite is $100 \mathrm{mg} \mathrm{kg}^{-1}$ and that superphosphates have $390 \mathrm{mg} . \mathrm{kg}^{-}$ 1 , mainly in its mobile form (Mirlean et al., 2003b).

The content of As varies considerably depending on the area in the estuary and time. However, other factors, such as granulometry, the organic content of the sediment (Förstner \& Wittman, 1981), physicochemical and geochemical conditions in the estuary and the frequency of dredging control As content in the bottom sediment (Urban et al., 2010).

Despite variability, higher values of As are usually found in the sediment at the Porto Novo and its surroundings, i. e., the Rio Grande Channel and other channels along the mouth of the Saco da Mangueira (Figure 1). In the Porto Novo region, As content tends to decrease along the Super Porto Channel up to the channel between the jetties. Sources from an old fertilizer plant located at the southern area of the Porto Novo (Figure 1A) and favorable conditions for sedimentation and accumulation of sediment in this region are factors that favor As enrichment.

Environmental studies conducted to assess the quality of superficial and sub-superficial sediments provide evidence of the previous observations. When the whole estuarine system is analyzed, i. e., considering all sandy and clayish sediments, the most usual variation ranges between 2 and $40 \mathrm{mg} \mathrm{kg}^{-1}$ of As. However, maximum values may exceed the level of $19 \mathrm{mg} \mathrm{kg}^{-1}$ of As established by the legislation (CONAMA, 2012), and recommended by Level 1.

The metals $\mathrm{Pb}, \mathrm{Cd}, \mathrm{Zn}, \mathrm{Cu}$ and $\mathrm{Cr}$ in superficial sediments of the estuary have a very similar distribution pattern. The highest values are found in more shallow waters which are adjacent to the main industrial, urban and port effluents (Baisch, et al., 1988; Asmus, 2008). Deeper zones, mainly in navigation channels, in general, have lower values of trace metals. These channels are constantly dredged and have high velocities of water flux reaching 1.7-1.9 $\mathrm{m} \mathrm{s}^{-1}$ after prolonged periods of heavy rain, while the maximum velocities of the current in the lagoon are approximately $0.3 \mathrm{~m} \mathrm{~s}^{-1}$ (Garcia, 1998). Dredged sediments are later deposited in a marine site. Usually, from 2 to 3 million tons of sediment are dredged every 2 or 3 years in order to maintain or deepen the channels and harbors areas (www.portoriogrande.com.br). Every dredging operation removes at least 0.5 to $1 \mathrm{~m}$ of superficial sediment from the navigation channels. However, dredging may resuspend the sediment and may cause dispersion of possible metals accumulated in the sediment.

\subsubsection{Speciation of trace metals in the sediment}

There have been some studies of metal speciation in the Patos Lagoon estuary (Baisch et al., 1988; Baisch, 1994). Oxy-hydroxides and, secondarily, sulphides and organic matter are the most important metal carriers in sediments of the Patos Lagoon estuary. On the other hand, Mirlean et al. $(2003 \mathrm{~b}, 2009)$ applied partial extractions for sediment samples and showed that As usually takes its labile form, while $\mathrm{Hg}$ does not.

Metal speciation and bioavailability of particulate sediment matter were assessed in urban and industrial effluents from the Patos Lagoon estuary. The domestic effluent, whose contamination was the result of untreated sewage, had high total concentrations in the effluent solid phase.

Sequential extractions in particulate matter from the effluents (Figure 3) revealed high values of $\mathrm{Cd}$ in the labile fraction $\left(\sum\right.$ exchangeable + carbonate + reducible + organic), mainly related to exchangeable fraction. There was a high percentage of $\mathrm{Pb}$ in the labile fraction, but it is linked mainly to oxy-hydroxides and the organic fraction. $\mathrm{Cu}$ and $\mathrm{Zn}$ were also associated with the labile fraction in the domestic effluent at higher levels, while $\mathrm{Ni}, \mathrm{Cr}$ showed lower values in the labile fractions in the industrial, domestic and mixt effluents. More than 50\% of the amount of $\mathrm{Cd}, \mathrm{Mn}, \mathrm{Pb}$ and $\mathrm{Zn}$ was associated with the labile fraction and domestic effluent, that is the most dangerous in terms of contamination risk to the local biota.Assessment of labile trace metals (direct extraction with $0.1 \mathrm{M} \mathrm{HCl}$ ) in the areas which were more affected - 


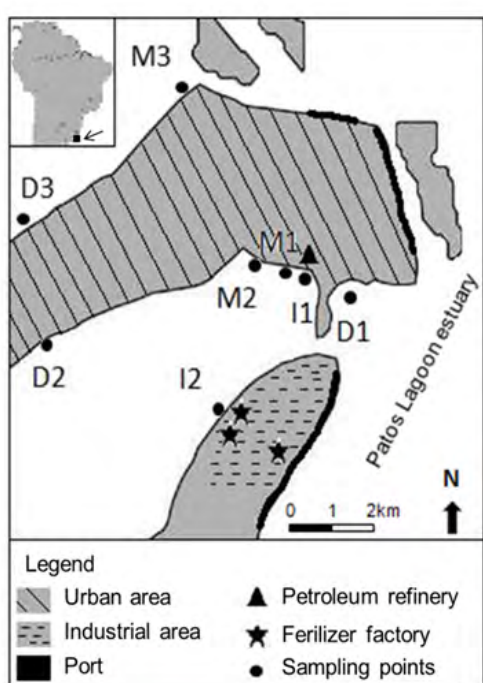

\begin{tabular}{|l|}
$\square$ Exchangeable \\
$\square$ Carbonate \\
$\square$ Reducible \\
$\square$ Organic \\
$\square$ Residual
\end{tabular}

$\mathrm{Cu}$

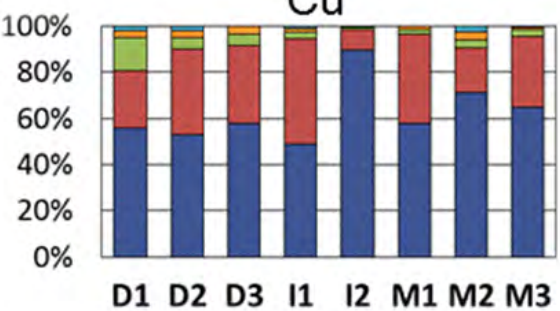

$100 \%$

$80 \%$

$60 \%$

$40 \%$

$20 \%$

$0 \%$

$100 \%$
$80 \%$
$60 \%$
$40 \%$
$20 \%$
$0 \%$
Cd

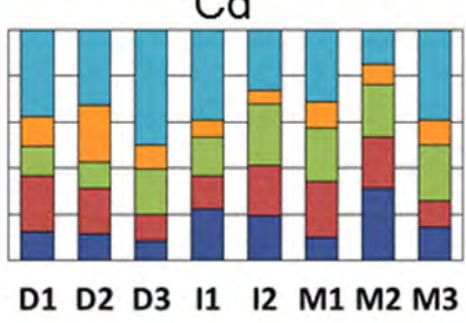

$\mathrm{Pb}$

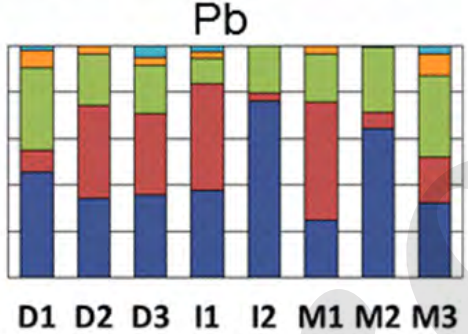

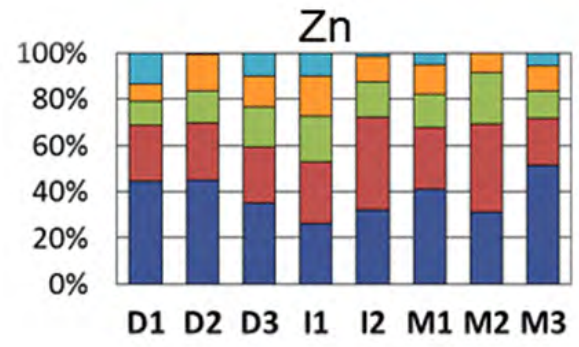
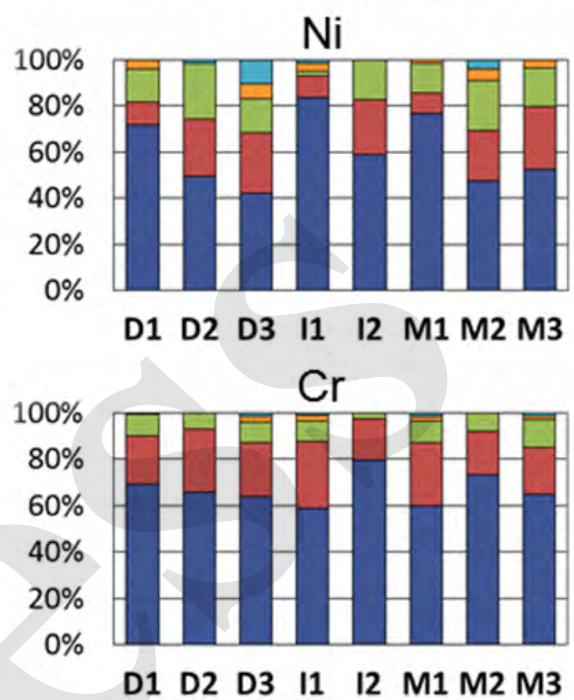

D1 D2 D3 11 - 12 M1 M2 M3

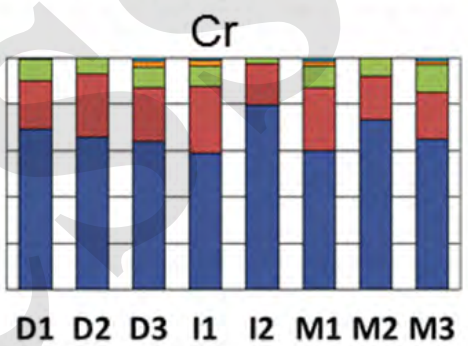

Figure 3 - Metal sequential extractions of particulate sediment matter from urban (D), industrial (I) and mixt (M) effluents from the Patos Lagoon estuary (adapted from Bento et al., 2013).

Figura 3 - Extração sequencial de metais do material particulado em suspensão de efluentes urbanos (D), industriais (I) e mistos (M) do estuário da Lagoa dos Patos (adaptado de Bento et al., 2013).

shipyard, marina and port shorelines waters - regarding the fine fractions of the sediment $(<0.63 \mu \mathrm{m})$ on a dry weight basis was recently carried out (Costa, 2012). Concentrations range from 3 to $768 \mathrm{mg} \mathrm{kg}^{-1}$ for $\mathrm{Cu}, 16$ to $578 \mathrm{mg} \mathrm{kg}^{-1}$ for $\mathrm{Zn}, 6$ to $178 \mathrm{mg} \mathrm{kg}^{-1}$ for $\mathrm{Pb}, 0.86$ to 3 $\mathrm{mg} \mathrm{kg}{ }^{-1}$ for $\mathrm{Cr}$ and 1 to $7 \mathrm{mg} \mathrm{kg}^{-1}$ for $\mathrm{Ni}$ were found. Most maximum concentrations exceed the typical values for continental crust (Taylor, 1964), with exception of $\mathrm{Cr}$ and $\mathrm{Ni}$. According to the Federal Resolution (CONAMA, 2012) on dredged sediment, concentrations of $\mathrm{Cu}, \mathrm{Zn}$ and $\mathrm{Pb}$ at the Irmão Fernandes Shipyard (which has operated for more than 100 years in the Porto Velho) exceeded Level 2, a fact that shows there may be adverse effect on the biota. However, $\mathrm{Cu}$ concentrations at the Santos Shipyard (which has operated for more than 20 years in the Super Porto) exceeded only Level 1, which is considered the attention level since there might be some adverse effects on the biota.

The extended El Niño effect on the region for six months caused a decrease in concentrations of labile metals in the sediment due to intense freshwater discharge. With the restoration of normal climatic conditions, water $\mathrm{pH}$ and salinity were found to be the main factors controlling the lability of metals in sediment (Costa, 2012).

\subsection{Atmosphere and soil compartments}

Garcia et al. (2010) observed that he influence of atmospheric emissions from the oil refinery in Rio Grande city (Figure 1) shows that the metal Ni and V have a strong relationship in the soil and therefore they are efficient markers of the chronic impact of these emissions on the estuarine region. Other elements under analysis $(\mathrm{Cd}, \mathrm{Cu}, \mathrm{Pb}$ and $\mathrm{Zn})$ did not have any relation with refining activities but resulted from other sources found in the urban, industrial and port complex in Rio Grande.

The As contamination in sediment and soil in the Patos Lagoon estuary was analyzed by studies carried out from 2003 to 2005 (Mirlean et al., 2003b; Mirlean \& Roisenberg, 2006) and by several environmental monitoring reports (www.portoriogrande.com.br). Other studies show the contamination by lead (122 $19,256 \mathrm{mg} \mathrm{kg}^{-1}$ ) (Mirlean et al., 2005b) and $\mathrm{Hg}(0.01$ $14 \mathrm{mg} \mathrm{kg}^{-1}$ ) in soil in Rio Grande (Conceição, 2005).

Atmospheric pollution caused by the presence of $\mathrm{Pb}$ and other trace metals $(\mathrm{Cd}, \mathrm{Cr}, \mathrm{Ni}, \mathrm{Cu}, \mathrm{Zn})$ in the atmospheric particulate matter smaller than $2.5 \mu \mathrm{m}$ $\left(\mathrm{PM}_{2.5}\right)$ was the theme of some studies, such as the ones published by Vanz (2000), Vanz et al. (2003), Mirlean 
et al. (2005b) and Gutierrez (2013). $\mathrm{Pb}\left(\mathrm{PM}_{100}\right)$ anomalous content was identified in solid atmospheric precipitation above $1000 \mu \mathrm{g} \mathrm{m}^{-3}$ (Vanz et al., 2003) (Figure 4). These studies showed that these urbanized regions in Rio Grande may be exposured to $\mathrm{Pb}$ concentrations, which exceed the established legal limits from USA $\left(1,5 \mu \mathrm{g} \mathrm{m}^{-3}\right)$ and East Europe $\left(0.7 \mu \mathrm{g} \mathrm{m}^{-3}\right)$ for $\mathrm{PM}_{10}$.

The main sources of atmospheric $\mathrm{Pb}$ are attributed not only to the fusion of $\mathrm{Pb}$ in the preparation of fishing apparatus and to the availability of residues on the soil but also to the use of paints with high content of $\mathrm{Pb}(\mathrm{Pb}$ oxide) on houses of poorer populations (Mirlean et al., 2005b).

In a study carried out by Mirlean \& Roiserberg (2006) in Rio Grande, the fertilizer plants and their activities were recognized as atmospheric sources of $\mathrm{Cd}$ and As. Moreover, this industrial sector had previously been known as the main responsible one for acid rains in Rio Grande, since $62 \%$ of the annual rainwater indicated $\mathrm{pH}$ values lower than 5.0 (Mirlean et al., 2000). The analysis of rainwater showed that $\mathrm{Cd}$ in the soluble form precipitates close to emission source, whereas As is transported farther and also in the soluble form precipitates at a greater distance. The $\mathrm{pH}$ controls the distribution of cadmium and arsenic in rain and groundwater. Concentration of soluble cadmium along the impact line increases with reduction of $\mathrm{pH}$ and arsenic, contrary to the increase in $\mathrm{pH}$. Concentrations of $\mathrm{Cd}$ and $\mathrm{As}$ in surface soil correlate well among themselves near to emission point (Mirlean \& Roiserberg, 2006).

Therefore, contributions given by atmospheric and soil contamination in Rio Grande must be taken into account when environmental assessment of water quality is carried out due to the potential anthropogenic input to the Patos Lagoon estuary. However, it is important to take into consideration the whole set of compartments in order to better assess the origin of an element, as was achieved by studies of $\mathrm{Hg}$ in the region (Mirlean et al., 2003a; Mirlean \& Oliveira, 2006; Mirlean et al.,2008).

\subsection{Mercury contamination: case study}

The first information on mercury pollution in the Patos Lagoon estuary was obtained in 1998 when the Chem Oil Company tanker with $12000 \mathrm{t}$ concentrated sulphuric acid had an accident and discharged part of the acid into their waters. Acid attack on the estuarine sediments led to metal redeposition along the trajectory of the acid effluent. Mercury anomaly with metal concentration of about $5 \mathrm{mg} \mathrm{kg}^{-1}$ in the sediment was found during the study of the accident (Mirlean et al., 2001).

The mercury content in sediments following the accident was much higher than the metal amount found in the sulphuric acid, making researchers look for the source of mercury pollution on the coast. The study of mercury distribution in the city effluents showed high values in particulate suspended matter. The highest $\mathrm{Hg}$ concentration (up to $21.1 \mathrm{mg} \mathrm{kg}^{-1}$ ) was found in domestic and mixed (domestic + runoff) effluents. It was evident that local industry effluents were not responsible for mercury pollution in the estuary (Mirlean et al., 2003a). However, the origin of the high mercury concentration in urban effluents was not revealed.

The existence of highly mercury polluted soil covers was reported in Rio Grande (Mirlean \& Oliveira, 2006). It was also found that, in historical buildings in the city, the concentrations of mercury reach up to $25 \mathrm{mg} \mathrm{kg}^{-1}$. Moreover, mercury contamination was detected in manmade ground (MG) deposits on all coastal reclamation sites of the city (Figure 5). It was observed that the older the MG, the higher the level of pollution. In the deposits dating from the beginning of the $18^{\text {th }}$ century (the very first coastal reclamation fill), mercury concentration are the highest registered value, i.e., almost 25 $\mathrm{mg} \mathrm{kg}^{-1}$. In the MG dating from the first half of the $19^{\text {th }}$ century, mercury concentration was almost twofold lower. Mercury concentration increases in MG's dating from the middle of the $20^{\text {th }}$ century: that are mainly composed of city garbage. Nevertheless, mercury concentration in deposits dating from the 20th century concedes that the oldest ones have both the highest registered concentration and the highest average value (Mirlean \& Oliveira, 2006).

Plausible sources of mercury in the $18^{\text {th }}$ century could be technological processes applied for felt production known as "carotting" which, at that time, included skin processing in mercury nitrate solutions. Absence of the neutralization of the used solutions, and any organized system of recycling of city garbage in general is the reason of a high level of pollution by mercury of environment that accordingly redounded to the high concentration of mercury in MG deposits of that time. However, a hundred years later, MG deposits were still highly polluted with mercury. The felt industry, initially represented by small workshops that joined into a large factory later, had been considerably developed by the end of the $19^{\text {th }}$ century. It may be confidently identified as the main source of mercury at that time. In the first half of the $20^{\text {th }}$ century, fast industrial growth demanded intensification of coastal reclamation. The MGs'were filled mainly by sand dune, lagoon sediments dredged during the deepening of the navigation channel and coal ash. The city garbage was a lot less used by comparison with earlier days. It explains the decrease in mercury concentration in MG material in the first half of the 20th century. Moreover the coastal reclamation planned and controlled by the Municipality, the city area also grew because of unregulated reclamation in its peripheral portion. Homeowners, whose backyards abutted on the coast, filled up shoal, thus, increasing their private areas. At such sites, any solid material and, more often, city garbage mixed up with beach sand were used. 


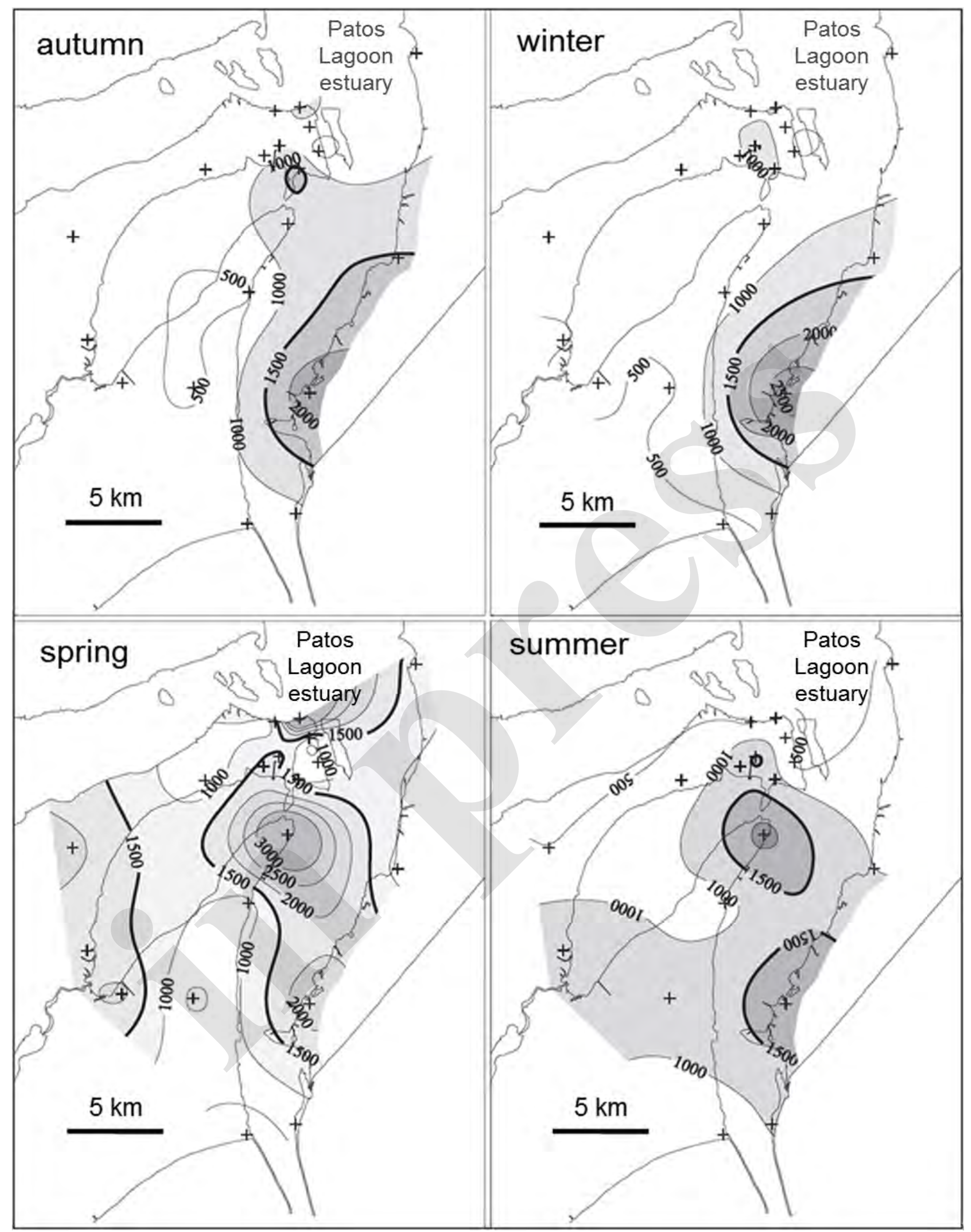

Figure 4 - Spatial distribution of $\mathrm{Pb}\left(\mathrm{mg} \mathrm{kg}^{-1}\right)$ in atmospheric particulate matter in four seasons in the estuary of the Patos Lagoon. (+) Sampling sites (Vanz et al., 2003).

Figure 4 - Distribuição especial de $\mathrm{Pb}\left(\mathrm{mg} \mathrm{kg}^{-1}\right)$ em material particulado atmosférico nas quatro estações sazonais no estuário da Lagoa dos Patos. (+) Locais de amostragem (Vanz et al., 2003). 


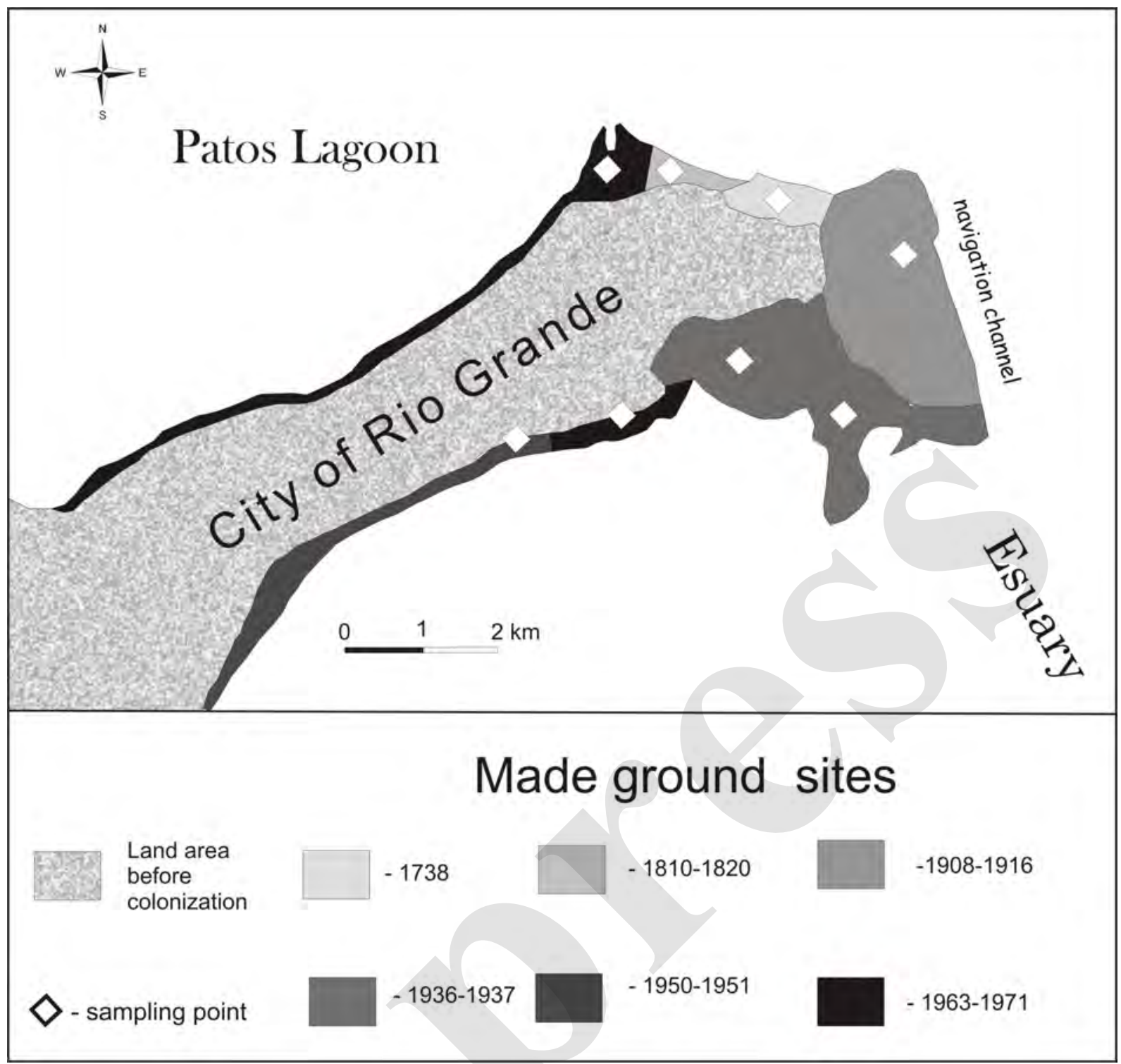

Figure 5 - Man-made ground sites of Rio Grande according to Mirlean \& Oliveira (2006).

Figure 5 - Locais de aterro na cidade do Rio Grande de acordo com Mirlean \& Oliveira (2006).

The MG' pollution provides explanation for mercury distribution in the whole environment in the region of Rio Grande city. The high concentration of particulate mercury in drainage effluents is most likely caused by small particles washed out from polluted MG'. Sediment of shoals near city coasts contains the highest amount of mercury $\left(17 \mathrm{mg} \mathrm{kg}^{-1}\right)$ in areas adjacent to the most polluted MG' (Mirlean et al., 2003a).

Mercury dispersion from soil and industrial emissions affects the large area around the city and enables $\mathrm{Hg}$ accumulation in fish (Mirlean et al., 2005a). It was demonstrated that mercury precipitation on lakes around the city increased closer to downtown and to industrial sources. Metal in fish tissue generally increased along the same gradient, but also varied with trophic level and preferred depth zone. Atmospheric mercury deposition on these closed lakes may be directly linked to concentrations in fish, with surface- feeding piscivorous species attaining the highest concentrations, which, in some cases, approximated and exceeded the threshold level of $0.5 \mathrm{mg} \mathrm{kg}^{-1}$ of total $\mathrm{Hg}$.

From 1998 to 2008, the distribution of mercury in the sediments of the Patos Lagoon estuary and nearby coastal marine deposits was monitored. Polluted urban soils and coastal reclamation fills were confirmed as the main sources of high mercury concentrations in shallow estuarine sediments which enter the navigation channel close to the urban area and are transported into the ocean. $\mathrm{Hg}$ concentration in sediments in the navigation channel has considerably increased since 2004 due to the intense reconstruction activity in the urban area (Mirlean et al., 2009). Periodic dredging of the channel strengthens the preconditions for coastal marine sediment contamination by mercury. However, it does not occur because the resuspended dredged sediments are significantly diluted by natural suspended particulate 
matter. This fact can be explained by a disproportionate volume of sediments being resuspended during dredging and sedimentary load being naturally deposited from the plume in the coastal zone. According to Calliari et al. (2007), approximately $30 \times 10^{6} \mathrm{~m}^{3}$ of sediment has been dredged (an annual average of $\left.1.5 \times 10^{6} \mathrm{~m}^{3}\right)$, and about $64 \times 10^{6} \mathrm{~m}^{3}$ deposited naturally (an annual average of $3.2 \times 10^{6} \mathrm{~m}^{3}$ ) during the last 20 years. Assuming that even up to $5 \%$ of the total dredge volume $\left(1.5 \times 10^{3} \mathrm{~m}^{3}\right)$ is suspended in estuarine water, this amount is a small part $(1 / 40)$ of the total volume of mud input in the coastal area by natural influence in the last 20 years.

Mercury pollution of soil in Rio Grande, which firstly occurred downtown in the 18th century and expanded in the $19^{\text {th }}$ and in the $20^{\text {th }}$ centuries, still impacts all compartments (soil, sediments, water, air and biota) of the surrounding environment.

\section{Current areas under impact in the estuary}

Studies carried out over the last 35 years in the estuary of the Patos Lagoon showed that there was an increase in the anthropogenic contributions of trace metals in several compartments of the environment. Even though the estuary is a quite dynamic environment, more sheltered areas, such as the Saco da Mangueira and other estuarine nearshore areas, have indicated water contamination because the inputs of potentially hazardous substances and sediment pollution as the inputs have been causing harmful effects. The low carrying capacity of the sheltered areas is attributed to their low hydrodynamics and little water renovation, moreover effluent directly discharged into them. Consequently, these areas close to the shore in the estuary can neither depurate nor restore, thus, generating an increase in environmental liabilities.

In order to summarize data provided by several studies carried out over many years, areas endangered by organic loads and trace metals around the city urban and industrial areas, including the three port areas, were mapped (Figure 6).

Most effluents that flow into the estuarine environment are clandestine, both urban and industrial. Strict environmental policies are needed to improve environmental estuarine quality, mainly in the Saco da Mangueira inlet. More control is needed to trigger, at least, basic effluent treatment which must be carried out by existing industries, residential condominiums and commercial buildings that are setting up in the region (Baumgarten, 2010).

The government must find a solution to the soils contaminated by the trace metals in Rio Grande municipality. Decrease in atmospheric particulate and in their acidity, mainly from fertilizer plants, must be aimed at.

\section{Environmental management measures}

The development of the Rio Grande city in the Patos Lagoon estuary has yielded conflicts of its resources use over the years and misappropriation of the city's shoreline areas has occurred as well. In general, the poor institutionalization of coastal management has been observed (Tagliani et al., 2003, 2007). In environmental terms, there has been a decrease in the diversity of benthic organisms in most impacted areas of the Saco da Mangueira (Bemvenuti and Angonesi, 2011) and the degradation of coastal habitats, such as dunes, inlets and salt marshes (Seeliger \& Costa, 1998). On large scale, there has been significant decline in fishery in the estuary since the end of the 1980's, a fact that has affected thousands of fishermen involved in the traditional activity (Reis \& D'Incao, 2000; Tagliani et al., 2003).

Such conflicts regarding the resources use and disposal of clandestine effluents from urban and industrial areas have produced a continued environmental degradation and affected the carrying capacity of the aquatic environment.

Measures are needed in order to inhibit discharge of clandestine and illegal industrial, domestic and naval effluents, which are rich in organic matter and trace metals, in the nearshore waters of the estuary, mainly in the inlets. If the increase input of nutrients into the estuarine waters is not controlled, dissemination and growth of opportunistic blooms may happen to an intolerable level for public health, mainly in the Saco da Mangueira (Baumgarten, \& Paixão, 2013). The uncontrolled contribution of trace metals to the water and their accumulation in sediment showed that some areas have been impacted, indicating a demand on the environmental control. This is evident due to labile metal concentrations that were found, since they can be potentially avaliable to all organisms. The atmospheric and soil contamination in Rio Grande must also be taken into account when environmental assessment of water quality is carried out, as a result of the potential anthropogenic input to the Patos Lagoon estuary. Particular attention should be paid to the element $\mathrm{Hg}$, because of its toxicity and its higher concentration in man-made ground of the city.

The peninsular shape of the city and the poor city control enables clandestine discharge of effluents to be connected to the city pluvial system, which flows into the estuary. The expansion of this system must be implemented and new systems must be designed in areas where industries have been built. Likewise, industries located in areas where there is no sewage collection, such as the industrial district and several condominiums on the nearshore waters of the estuary, should be requested to implement private sewage treatment systems. 


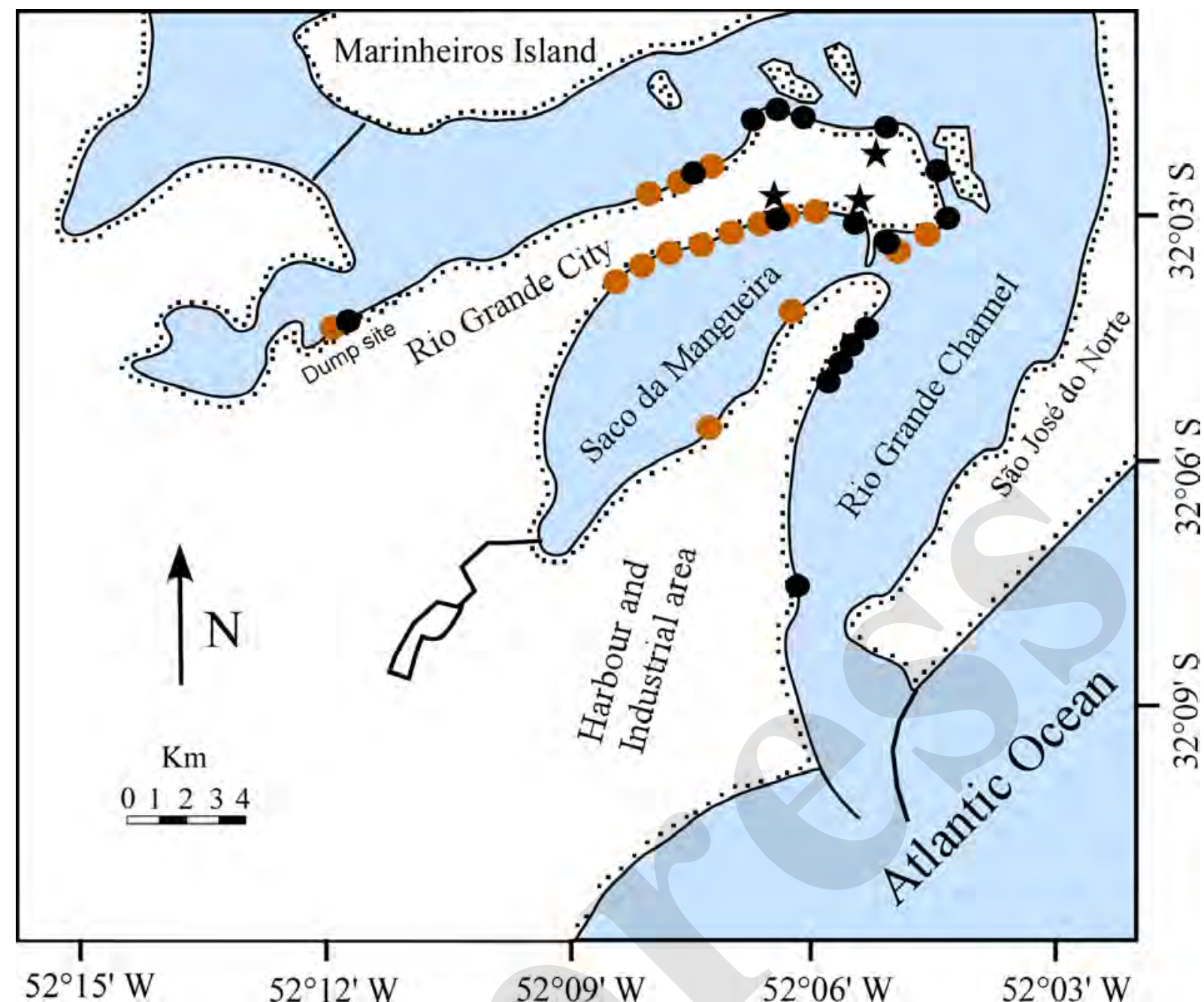

Figure 6 - Locations around the Rio Grande city and its industrial and port areas, indicating the more contaminated areas by organic matter in the water $(\bigcirc)$ and trace metals in the sediment $(\mathbf{O})$ and soil $(\star)$ ). Water data according to Aguiar \& Baumgarten (2014) and Sprengler et al. (2007); sediment data according to Mirlean et al. (2003a and b, 2009) and Costa et al. (unpublished data) and soil data according to Mirlean, et al.(2005b, 2006, 2008) and Mirlean \& Roiserberg (2006).

Figura 6 - Locais ao redor da cidade de Rio Grande e sua área industrial e portuária, indicando as áreas mais contaminadas por matéria orgânica na água (○), metais traço no sedimento $(\mathbf{O})$ e em solos $(\boldsymbol{\uparrow})$. Dados em água segundo Aguiar \& Baumgarten (2014) e Sprengler et al. (2007); dados em sedimento segundo Mirlean et al. (2003a e b, 2009) e Costa et al. (dados não publicados) e dados em solos de acordo com Mirlean, et al. (2005b, 2006, 2008) e Mirlean \& Roiserberg (2006).

The Municipal Plan of Basic Sanitation became official in 2013; it has an overview of environmental problems faced by the whole city as well as political and structural solutions that the city hall must implement. Therefore, it must be implemented as soon as possible to improve environmental quality.

The increase trends in environmental liabilities around the city demands the mitigations of the socioenvironmental conflict (Tagliani et al., 2007). Therefore, regulations issued by the Municipality of Rio Grande resulted in the Southern Coast Program, which is part of the Rio Grande Municipal Environmental Plan that focuses on environmental management (Tagliani \& Polette, 2011). It included the Local Harbor Agenda, which establishes an environmental program for all the three harbors. Based on these local resolutions and ac- cording to Anello \& Koehler (2011), neither liquid effluents nor atmospheric emissions are, in many cases, within the limits established by local legislation.

Although several initiatives and advances have been achieved under the Southern Coast Program, the consolidation of an integrated management program for the Patos Lagoon estuary requires the development of several activities based on a clear action strategy (Tagliani et al., 2011). However, the institutional structure and fragility of the country perhaps becomes the bigger challenge for the implementation of an effective integrated coastal management program for this area as pointed out by Tagliani et al. (2003).

The city government must implement an integrated management program for the estuary in a real and practical way, involving stakeholders and local governments 
as suggested by USEPA's Community-Based Environmental Protection (Brown et al., 2002). The studies under analyses in this paper clearly show the temporal evolution of environmental impacts on several areas of the estuary. An environmental policy based on the mapping of the biodiversity and the liabilities should be set to in the long term. The state environmental agency must also act more effectively to supervise industrial liquid effluents and atmospheric emissions. If this set of actions is not quickly and adequately implemented, it may endanger the environment and the population's life quality in the southern region of the estuarine system.

\section{Appendix}

Supporting Information associated with this article is available online at http://www.aprh.pt/rgci/pdf/rgci-596_WallnerKersanach_Supporting-Information.pdf

\section{References}

Abreu, P.C.; Odebrecht, C.; Niencheski, L.F. (2010) - Nutrientes dissolvidos. In: Ulrich Seeliger; Clarisse Odebrecht (org.), $O$ estuário da Lagoa dos Patos, pp.43-48, Editora FURG, Rio Grande, RS, Brasil. ISBN: 978-8575661444.

Aguiar, V.F.; Baumgarten, M.G.Z.; Rodrigues, H. (2014) - Identificação e diagnóstico dos locais de lançamento de efluentes nas margens da enseada estuarina Saco da mangueira (Rio Grande, RS). Anais do Congresso Brasileiro de Oceanografia (ISBN: 978-85-66184-03-7), pp. 1793-1792, Itajaí, Brazil. Available on line at http://www.aoceano.org.br/site/images/pdf/livro_de_resumos_cbo201 4.pdf

Almeida, M.T.A.; Baumgarten, M.G.Z.; Kinas, P.G.; Kantin, R. (1984) - Estudo da poluição orgânica das águas das imediações da cidade do Rio Grande (RS, Brasil). Revista Atlântica (ISSN 2236-7586), 7:15-24, Editora FURG, Rio Grande, RS, Brasil.

Almeida, M.T.A.; Baumgarten, M.G.Z.; Rodrigues, R.M.O. (1993) Identificação das possiveis fontes de contaminação das águas que margeiam a cidade do Rio Grande-RS. 36p., Série Documentos Técnicos em Oceanografia No. 6, Editora FURG, Rio Grande, RS, Brazil.

Anello, L.F.; Koehler, P.H.W. (2011) - Integração do sistema de gestão ambiental do Complexo Portuário - Industrial. In: Paulo Tagliani, Milton Asmus. (Org.), Manejo Integrado do Estuário da Lagoa dos Patos, pp.61-72, Editora da FURG, Rio Grande, RS, Brazil. ISBN: 978-8575662069.

Asmus, M.; Baisch, P.; Baugarten, M. G.Z.; Bemvenuti, C. E.; Filmann, G.; Niencheski, L. F.; Taglianni, P.; Wallner, M. (2008) - Programa de monitoramento ambiental do Porto de Rio Grande. III Simpósio de Dragagens Portuárias do Brasil Engenharia, Tecnologia e Meio Ambiente, MCT, 1:114-135, Curitiba, Brasil.

Baisch, P.; Niencheski, F.; Lacerda, L. (1988) - Trace metals distribution of Patos Lagoon estuary. In: Ulrich Seeliger, Luis Drude de Lacerda; Sambasiva Rao Patchineelam (org.), Metals in Coastal Environments of Latin America, pp.59-64, Springer-Verlag. Berlin, Germany. ISBN: 978-3642714856.

Baisch, P. (1994) - Les oligo-éléments métalliques du système fluvio-lagunaire dos Patos, Flux et Dévenir (Brésil). 345p., Thèse de Doctorat, Université de Bourdeaux I, Bourdeaux, France. Unpublished.

Barbosa, F.G.; Wallner-Kersanach, M.; Baumgarten, M.G.Z. (2012) - Metais traço nas águas portuárias do estuário da Lagoa dos
Patos, RS. Brazilian Journal of Aquatic Science and Technology (ISSN: 1808-7035), 16(2):27-36, Itajaí, Brasil. Available on-line at http://siaiweb06.univali.br/seer/index.php/bjast/article/view/3401/243 5

Baumgarten, M.G.Z.; Niencheski, L.F.; Kuroshima, K. N. (1995) Qualidade das águas estuarinas que margeiam o município do Rio Grande (RS): Nutrientes dissolvidos. Revista Atlântica, (ISSN: 2236-7586), 17(1):17-34, Editora FURG, Rio Grande, RS, Brasil.

Baumgarten, M.G.Z. (2010) - A eutrofização das águas de uma enseada do estuário da Lagoa dos Patos (RS) protegida pela legislação ambiental. Fepam em Revista (ISSN 1982-2162), 3(2):34-42, Porto Alegre, Brasil. Available on-line at http://www.fepam.rs.gov.br/fepamemrevista/downloads/Revista_V3N 2\%20-\%202010\%20-\%20LEVE.pdf

Baumgarten, M.G.Z.; Wallner-Kersanach, M.; Niencheski, L.F.H. (2010) - Manual de Análises em Oceanografia Química. 172p., Editora FURG, Rio Grande, Brasil. ISBN: 9788575661413.

Baumgarten, M.G.Z.; Paixão, B.E.G. (2013) - Uso do índice do estado trófico para avaliar a qualidade das águas do estuário da Lagoa dos Patos (RS). Revista Atlântica (ISSN: 22367586), 35(1):5-22, Rio Grande, Brasil. Available online at http://www.seer.furg.br/atlantica/article/view/2965/2996.

Bento D.M.; Mirlean, N.; Baisch, P. (2013) - Metal speciation in urban-industrial effluents: impact assessment for an estuary in southern Brazil. Fresenius Environmental Bulletin (ISSN: 1018-4619), 22(4a):1-8, Technische Universität München, München, Germany.

Bemvenuti, C.E.; Angonesi, L.G. (2011) - A qualidade ambiental da enseada estuarina Saco da Mangueira: Estrutura da Comunidade Bentônica. In: Paulo Tagliani; Milton Asmus. (org.), Manejo Integrado do Estuário da Lagoa dos Patos, pp.201206, Editora da FURG, Rio Grande, RS, Brasil. ISBN: 9788575662069 .

Brown, B.S.; Munns Jr, W.R.; Pau, J.F. (2002) - An approach to integrated ecological assessment of resource condition: the Mid-Atlantic estuaries as a case study. Journal of Environmental Management, 66:411-427. DOI: 10.1006/jema.2002.0598

Burgin, S.; Hardiman, N. (2011) - The direct physical, chemical and biotic impacts on Australian coastal waters due to recreational boating. Biodiversity and Conservation, 20 (4):683701. DOI: $\underline{10.1007 / \mathrm{s} 10531-011-0003-6}$

Calliari, L.J.; Holland, K.T.; Pereira, P.S.; Guedes, R.M.C.; Espírito Santo, R. (2007) - The influence of mud on the inner shelf, shoreface, beach and surf-zone morphodynamics-Cassino, Southern Brazil. Proceedings of 7th Conference on Coastal Sediments, 2:1455-1465, New Orleans, U.S.A. Available online at http://www.praia.log.furg.br/Publicacoes/2007/2007b.pdf

Cicin-Sain, B.; Knecht, R.W. (1998) - Integrated Coastal and Ocean Management: concepts and practices. 517p., Island Press, Washington, United States of America. ISBN: 1559636041 .

Clark, R. B. (2001) - Marine Pollution. 161p., Oxford University Press, Oxford, Great Britain. ISBN: 0198792921.

CONAMA (2012) - Conselho Nacional do Meio Ambiente. Resolução $n^{\circ}$ 454. 01 de Novembro de 2012. DOU de 08 de Novembro de 2012. Revoga a Resolução CONAMA n ${ }^{\circ} 344$ de 2004 e 421 de 2010. Available online at http://www.mma.gov.br/port/conama/legiabre.cfm?codlegi=693

Conceição, C.O. (2005) - Contaminação dos aterros urbanos por metais pesados no município - Rio Grande (RS). 115p, Dissertação de Mestrado, Universidade Federal do Rio Grande, Rio Grande, RS, Brasil. Unpublished. 
Corradi, C.E.; Braumgarten, M.G.Z.; Niencheski, L.F.H.; WallnerKersanach, M. (2007) - Monitoramento hidroquímico da área do Porto do Rio Grande (RS) submetida a atividades de dragagem. In: Eliane Bêe Boldrini; Carlos Alberto Soares; Eduardo Vedro de Paula (org.), Dragagens Portuárias no Brasil - Licenciamento e Monitoramento Ambiental, pp.7778, Ministério de Ciência e Tecnologia, Brasília, Brasil.

Costa, N.R.; Kantin, R.; Niencheski, L. F.; Batista, J.R.; Braumgarten, M.G.Z. (1982) - Estudo da poluição orgânica nas águas que rodeiam a cidade de Rio Grande. Engenharia Sanitária e Ambiental (ISSN: 1413-4152), 21(2):222-231, ABES Associação Brasileira de Engenharia Sanitária e Ambiental, Rio de Janeiro, RJ, Brasil.

Costa, L.D.F. (2012) - Avaliação de metais na forma lábil no sedimento e na água de marinas e áreas portuárias de Rio Grande, RS, na Lagoa dos Patos sob influência do uso de tintas anti-incrustantes em embarcações. 110p., Dissertação de doutorado Universidade Federal do Rio Grande, Rio Grande, RS, Brasil. Unpublished.

Costa, L.D.F; Wallner-Kersanach, M. (2013) - Assessment of labile fraction of copper and zinc in marinas and port areas in southerm Brasil. Environmental Monitoring and Assessment, 185:6767-6781. DOI: 10.1007/s10661-013-3063-0

Davison,W.; Zhang, H. (1994) - In situ speciation measurement of trace components in natural waters using thin-film gels. Nature, 367: 546-548. DOI: 10.1038/367546a0

Domingues, M.V. de la R.; Carvalho, D.S.; Carvalho, A.B. (2013) O Polo Naval e Offshore e o desenvolvimento regional da metade sul do Rio Grande do Sul. Ensaios FEE (ISSN: 19802668), 34:933-954, Porto Alegre, Brasil. Available on-line at http://revistas.fee.tche.br/index.php/ensaios/article/view/3053/3201.

Dunn, R.J.K.; Teasdale, P.R.; Warnken, J.; Schleich, R.R.; (2003) Evaluation of the diffusive gradient in a thin film technique for monitoring trace metal concentrations in estuarine waters. Environmental Science and Technology, 37: 2794-2800. DOI: 10.1016/j.envpol.2006.10.027

Förstner, U.; Wittman G. (1981) - Metal Pollution in the Aquatic Environment. Springer. 486 p., Berlin, Heidelberg, Germany. ISBN: 978-3540128564.

Garcia, C.A.E. (1998) - Características hidrográficas. In: Ulrich Seeliger; Clarisse Odebrecht; Jorge P. Castello (org.), Os Ecossistemas Costeiros e Marinhos do Extremo Sul do Brasil, pp. 219-226, Editora Ecoscientia, Rio Grande, RS, Brasil. ISBN: $354061365 \mathrm{x}$.

Garcia, F.A.P.; Mirlean, N.; Baisch, P.R. (2010) - Marcadores metálicos como avaliação de impacto crônico de emissões petroquímicas em zona urbana. Química Nova (ISSN 1678-7064), 33(3):716-720, São Paulo, Brasil. Available on-line at http://quimicanova.sbq.org.br/imagebank/pdf/Vol33No3_716_39NT09017.pdf

Gutierrez, F.B. (2013) - Estudo do material particulado atmosférico (MP 2,5) em áreas adjacentes a Laguna dos Patos em Rio Grande, RS- Rio Grande (RS). 138 p., Dissertação de Mestrado, Universidade Federal do Rio Grande, Rio Grande, RS, Brasil. Unpublished.

Herz, R. (1977) - Circulação das aguas superficiais da Lagoa dos Patos. 217 p., Dissertação de Doutorado, Universidade de São Paulo, São Paulo, SP, Brasil. Unpublished.

Kantin, R.; Costa, N.R.; Baptista, J.R.; Philomena, A.L.; Giesta, S.M.; Niencheski, L.F. (1980) - Contaminação das águas ao redor da cidade do Rio grande: óleos e graxas. Ciência e Cultura (ISSN: 2317-6660), 33(2):236-239, Campinas, Brasil.

Kantin, R.; Baumgarten, M.G.Z.; Cabeda, M.; Beaumond, A.C; Almeida, T.L. (1981) - Concentration of anionic detergents in
Rio Grande water (South of Brasil). Marine Pollution Bulletin, 12:50-53. DOI: 10.1016/0025-326X(81)90259-9

Kjerfve, B. (1986) - Comparative oceanography of coastal lagoons. In: Douglas A. Wolfe (org.), Estuarine Variability, pp.63-81, N.Y. Academic Press., Orlando, FL, U. S. A. ISBN: 0127618902.

Law, R.J.; Kelly, C.; Matthiessen, P.; Aldridge, J. (2003) - The loss of the chemical tanker Ievoli Sun in the English Channel, October 2000. Marine Pollution Bulletin, 46(2):254-257. DOI: 10.1016/S0025-326X(02)00222-9

Leeuwen, H.P.V.; Town, R.M.; Buffle, J.; Cleven, R.F.M.J.; Davison, W.; Puy, J.; Riemsdijk, W.H.V.; Sigg, L. (2005) - Dynamic speciation analysis an biovailability of metals in aquatic system. Environmental Science and Technology, 22: 85458556. DOI: $10.1021 / \mathrm{es} 050404 \mathrm{x}$

Long, E.R.; Macdonald, D.D.; Smith, S.L.; Calder, F.D. (1995) Incidence of adverse biological effects within ranges of chemical concentrations in marine and estuarine sediments. Environmental Management (ISSN: 1432-1009), 19(1):81-97. Available online at http://link.springer.com/journal/267/19/1

Mirlean, N.; Vanz, A.; Baisch, P. (2000) - Níveis e origem da acidificação das chuvas na região de Rio Grande, RS. Química Nova (ISSN: 1678), 23(5):590-593. Available on-line at http://quimicanova.sbq.org.br/imagebank/pdf/Vol23No5_590_03.pdf

Mirlean, N.; Baraj, B.; Niencheski, L. F.; Baisch, P.; Robinson, D. (2001) - The effect of accidental sulphuric acid leaking on metal distributions in estuarine sediment of Patos Lagoon. Marine Pollution Bulletin, 42(11):1114-1117. DOI: 10.1016/S0025-326X(01)00099-6

Mirlean, N.; Andrus, V.; Baisch, P. (2003a) - Mercury pollution sources in sediments of Patos Lagoon Estuary, Southern Brazil. Marine Pollution Bulletin, 46(3):331-334. DOI: 10.1016/S0025-326X(02)00404-6

Mirlean,N.; Andrus, V.E.; Baisch, P.;Griep, G.; Casartelli, M.R. (2003b) - Arsenic pollution in Patos Lagoon estuarine sediments. Marine Pollution Bulletin, 46(11):1480-1484. DOI: 10.1016/S0025-326X(03)00257-1

Mirlean, N.;Larned, S.; Nikora, V.; Kutter, V. (2005a) - Mercury in lakes and lake fishes on a conservation-industry gradient in Brazil. Chemosphere, 60(2): 226-236. DOI: 10.1016/j.chemosphere.2004.12.047

Mirlean, N.; Robinson, D.; Kawashita, K.; Vignol, M. L.; Conceição, R; Chemale, F. (2005b) - Identification of local sources of lead in atmospheric deposits in an urban area in Southern Brazil using stable lead isotope ratios. Atmospheric Environment, 39(33):6204-6212. DOI: 10.1016/j.atmosenv.2005.07.002

Mirlean, N.; Oliveira, C. (2006) - Mercury in coastal reclamation fills in southernmost Brazil: Historical and environmental facets. Journal of Coastal Research, 22(6):1573-1576. DOI: 10.2112/04-0352.1

Mirlean, N.; Roisenberg, A. (2006) -The effect of emissions of fertilizer production on the environment contamination by cadmium and arsenic in southern Brazil. Environmental Pollution, 143(2):335-340. DOI: 10.1016/j.envpol.2005.11.022

Mirlean, N.; Calliari, L.J.;Baisch, P.; Loitzanbauer, E.; Shumilin, E. (2009) - Urban activity and mercury contamination in estuarine and marine sediments (Southern Brazil). Environmental Monitoring and Assessment, 157(1):583-590. DOI: 10.1007/s10661-008-0558-1

Möller, O.O.; Castaing, P. (1999) - Hydrological characteristics of the estuarine area of Patos Lagoon (30 ${ }^{\circ} \mathrm{S}$, Brazil). In: Gerardo M.E. Perillo; María Cintia Piccolo; Mario Pino-Quivira (org.), Estuaries of South America: their geomorphology and dynamics, pp.83-100, Springer-Verlag, Berlin, Germany. 
Niencheski, L.F.H.; Baumgarten, M.G.Z.; Fillmann, G.; Window, H. L. (1999) - Nutrients and suspended matter behaviour in the Patos Lagoon Estuary (Brazil). In: Gerardo M.E. Perillo; María Cintia Piccolo; Mario Pino-Quivira (org.), Estuaries of South America: their geomorphology and dynamics, pp.67-81, Springer-Verlag, Berlin, Germany.

Niencheski, L.F.H.; Baumgarten, M.G.Z. (2000) - Distribution of particulate trace metal in Southern Part of the Patos Lagoon Estuary. Aquatic Ecosystem Health and Management, 3(4):515-520. DOI: 10.1016/S1463-4988(00)00041-5

Odebrecht, C; Abreu,P.C.; Bemvenuti, C.E.; Copertino, M.; José H. Muelbert, J.H.; Vieira, J.P.; Seeliger, U. (2010) - The Patos Lagoon Estuary, Southern Brazil - Biotic Responses to Natural and Anthropogenic Impacts in the Last Decades (19792008). In: Michael J. Kennish, Hans W. Paerl (org.), Coastal Lagoons: Critical Habits of Environmental Change, pp. 434455, CRC Press, Boca Raton, FL, U.S.A.. ISBN: 9781420088311 .

Pasquini, A.I.; Niencheski, L.F.H.; Depetris, P.J. (2012) -Yhe ENSO signature and other hydrological characteristics in $\mathrm{Pa}-$ tos and adjacente coastal lagoons, South-eastern Brazil. Estuarine, Coastal and Shelf Science, 111:139-146. DOI: 10.1016/j.ecss.2012.07.004

Persich, G.R.; Odebrecht, C.; Bergesch, M.; Abreu, P.C. (1996) Eutrofização e fitoplâncton: comparação: comparação entre duas enseadas rasas do estuário da Lagoa dos Patos. Revista Atlântica, (ISSN on line: 2236-7586 / ISSN print: 0102165635), 18:27-41, Rio Grande, RS, Brasil. Available on-line at http://www.seer.furg.br/atlantica.

Pinheiro Junior, E.M.; Baumgarten, M.G.Z.; Souza, M.L. ( 2010) A poluição das águas por matéria orgânica: uma abordagem didática para o ensino fundamental. In: Raquel Pereira Quadrado, Maria Teresa O. Nunes, Cláudia Andréa Z. Rizzi, Paula Regina C. Ribeiro (org.), Ecos do Sul: conhecer os ecossistemas costeiros é tri legal. pp.210-229, Editora da FURG, Rio Grande, RS, Brasil . ISBN: 978-8575661475.

Reis, E.G.; D'incao, F. (2000) - The present status of artisanal fisheries of extreme southern Brazil: an effort towards community based management. Ocean \& Coastal Management, 43(7):585-595. DOI: 10.1016/S0964-5691(00)00048-X

Salomons, W.; Förstner, U. (1984) - Metals in the hydrocycle. 349 p., Springer-Verlag. Berlin, Heidelberg, Germany. ISBN: 3540127550 .

Seeliger, U.; Costa, C.S.B. (1998) - Impactos Naturais e Humanos. In: Ulrich Seeliger; Clarisse Odebrecht; Jorge P. Castello (org.), Os Ecossistemas Costeiros e Marinhos do Extremo Sul do Brasil, pp.219-226. Editora Ecoscientia, Rio Grande, RS, Brazil. ISBN: 354061365x

Shumilin, E.; Paez-osuna, F.; Green-ruiz, C.; Sapozhnikov, D.; Guadalupe, D.; Rodriguez-meza, G.D.; Godrınez-orta, L. (2001) - Arsenic, antimony, selenium and other trace elements in sediments of the La Paz Lagoon, Peninsula of Baja, California, Mexico. Marine Pollution Bulletin, 42(3):174-178, Great Britain. DOI: 10.1016/S0025-326X(00)00123-5

Souza, P.R.S. (2011) - Áreas urbanas desfavorecidas do município de Rio Grande/RS. 118p., Dissertação de Mestrado em Geografia, Universidade Federal do Rio Grande, Rio Grande, RS, Brasil.. Unpublished.

Spengler, A.; Wallner-Kersanach, M.; Baumgarten, M.G.Z. (2007) Rio Grande Municipal dump site impact in the estuary of the Patos Lagoon ( RS, Brazil). Acta Liminologica Brasilensia,
(ISSN 2179-975x), 19(2):197-210, Rio Claro, Brasil. Available on-line at http://www.ablimno.org.br/acta/pdf/acta19_vol2_07.pdf

Tagliani, P.R.A.; Landazurib, H.; Reis, E.G.; Tagliani, C.R.; Asmus, M.L.; Sánchez-Arcilla, A. (2003) - Integrated coastal zone management in the Patos Lagoon estuary: perspectives in context of developing country. Ocean \& Coastal Management, 46(9-10):807-822. DOI: 10.1016/S0964-5691(03)00063-2

Tagliani, P.R.A.; Asmus; M.L.; Tagliani, C. R. A.; Polette, M.; Costa, C. S. B.; Salas, E. (2007) - Integrated Coastal zone mangement in the Patos Lagoon Estuary (south Brazil): State of art. In: C. A. Brebbia; A. Kungolos (org.). Water Resources Management IV, pp. 679-686, Wit Press, Southampton, UK. ISBN: 978-1845640743.

Tagliani, P.R.A.; Kitzmann, D.; Asmus, M.L. (2011) - As forças e as debilidades, as opportunidades e as ameaças no manejo integrado no estuário da Lagoa dos Patos. In: Paulo Tagliani; Milton Asmus. (org.), Manejo Integrado do Estuário da Lagoa dos Patos, pp. 219-232, Editora da FURG, Rio Grande, RS, Brasil. ISBN: 978-8575662069.

Tagliani, P.R.; Polette, M. (2011) - O sistema municipal de Monitoramento . In: Paulo Tagliani; Milton Asmus. (org.), Manejo Integrado do Estuário da Lagoa dos Patos, pp. 191-199, Editora da FURG, Rio Grande, RS, Brasil. ISBN: 9788575662069 .

Torres, L.H. (2008) - Cronologia básica da história da cidade do Rio Grande (1737-1947). Biblos, (ISSN: 0102-4388), 22(2):9-18, Rio Grande, RS, Brasil. Available online at http://www.seer.furg.br/biblos/article/view/957/424

Urban, S.R.; Corrêa, A.X.R.; Schettini, C.A.F.; Schwingel, P.R.; Sperb, R.P.; Radetski, C.M. (2010) - Physicochemical and ecotoxicological evaluation of estuarine water quality during a dredging operation. Journal of Soil Sediments, 10(1):65-76. DOI: $10.1007 / \mathrm{s} 11368-009-0156-\mathrm{Z}$

Vanz, A. (2000) - Estudo Geoquímico das Precipitações Sólidas Atmosféricas na Região do Rio Grande. 119p., Dissertação de Mestrado, Fundação Universidade Federal do Rio Grande, Rio Grande, RS, Brasil. Unpublished.

Vanz, A.; Baisch, P.; Mirlean, N. (2003) - Avaliação de poluição do ar por chumbo particulado através de uma abordagem geoquímica. Química Nova, 26(1):25-31, São Paulo, Brasil. Available on-line
http://quimicanova.sbq.org.br/imagebank/pdf/Vol26No1_25_05.pdf

Wallner-Kersanach, M.; Andrade, C.F.F.; Milani, M.R.; Niencheski, L.F.H. (2009) - In situ measurement of trace metals in estuarine waters of the Patos Lagoon using the diffusive gradient in thin film (DGT). Journal of Brazilian Chemical Society, 20,(2):333-340. DOI: 10.1590/S0103-50532009000200019

Warnken, J.; Dunn, R.J.K.; Teasdale, P.R. (2004) - Investigation of recreational boats as a source of copper at anchorage sites using time-integrated diffusive gradients in thin film and sediment measurements. Marine Pollution Bulletin, 49(9-10):833843. DOI: $10.1016 /$ j.marpolbul.2004.06.012

Windom, H. L.; Niencheski, L. F.; Smith, R. G. Jr. (1999) - Biogeochemistry of Nutrients and Trace Metals in the Estuarine Region of the Patos Lagoon (Brazil). Estuarine, Coastal and Shelf Science, 48(1):113-123. DOI: 10.1006/ecss.1998.0410

Yunes, J.S.; Salomon, P.S.; Matthiensen, A.; Beattie, K.A.; Raggett, S.L.; Codd, G.A. (1995) - Toxic blooms of cyanobacteria in the Patos Lagoon Estuary, southern Brazil. Journal of Aquatic Ecosystem Health, 5(4):223-229. DOI: 10.1007/BF00662183 